\title{
Pengaruh Penambahan Tepung Ulat Sagu Pada Pakan Buatan Terhadap Pertumbuhan Dan Kelangsungan Hidup Benih Ikan Nila Di Wadah Terkontrol
}

\author{
Sago Flour Addition Effect On Worm Artificial Feed On The Growth And \\ Survival Seed In Containers Controlled Fish Indigo \\ ${ }^{1}$ Sudirto Malan dan Riksanjani' \\ ${ }^{1}$ Program Studi Budidaya Perairan, FPIK-UNKHAIR \\ E-mail : sudirtomalam078@gmail.com
}

\begin{abstract}
ABSTRAK
Ikan nila (Oreochromis niloticus) merupakan salah satu komoditas perikanan yang digemari masyarakat dalam memenuhi kebutuhan protein hewani karena memiliki daging yang tebal serta rasa yang enak. Salah satu faktor penting yang mempengaruhi pertumbuhan ikan adalah pakan. Pakan merupakan salah satu unsur penting dalam kegiatan budidaya. Penelitian ini bertujuan Mengetahui pengaruh penambahan tepung ulat sagu pada pakan buatan terhadap pertumbuhan dan kelangsungan hidup ikan nila dan dapat mengetahui dosis tepung ulat sagu yang baik terhadap kualitas pakan buatan untuk pertumbuhan dan kelangsungan hidup ikan nila (Oreochromis niloticus). Penelitian ini dilaksanakan Pada bulan Oktober sampai bulan November 2018. di Laboraturium Basah Kastela Fakultas Perikanan Dan Kelautan Universitas Khairun Ternate. Rancangan yang digunakan dalam penelitian ini adalah Rancangan Acak Lengkap (RAL) dengan 4 perlakuan dan 3 kali ulangan. Perlakuan yang digunakan adalah penambahan tepung ulat sagu A 20 gr dari 100 gram pakan, B sagu 25 gr dari 100 gram pakan, C 30 gr dari 100 gram pakan, D pakan komersil (kontrol). Hasil penelitian menunjukan bahwa Pertumbuhan mutlak tertinggi terdapat pada pelakuan D pakan komersil (kontrol) sebesar 8,54 gram, diikuti perlakuan C sebesar 5,98 gram, perlakuan B sebesar 5,64 gram dan perlakuan A sebesar 4,84 gram. Pertumbuhan sesaat SGR nilai tertinggi diperoleh pada perlakuan D pakan komersil (kontrol) sebesar 3,87 gram di ikuti dengan perlakuan $C$ sebesar 3,82 gram, perlakuan B sebesar 3,81 gram dan yang terendah perlakuan A yaitu sebesar 3,80 gram. Tingkat kelangsungan hidup benih ikan nila selama 28 hari pada tiap-tiap perlakuan memiliki nilai yang sama, yaitu $100 \%$.
\end{abstract}

Kata Kunci: Ikan Nila, Pertumbuhan, Tingkat Kelangsungan hidup

\section{ABSTRACT}

Tilapia (Oreochromis niloticus) is the one commodity that is popular with the public in meeting the needs of animal protein because they have thick flesh and good taste. One important factor affecting the growth of the fish are feeding. Feed is one important element in farming activities.This study aims to know the effect of the addition of sago starch in artificial diet on the growth and survival of tilapia and to know dose sago flour well to the quality of artificial feed for the growth and survival of tilapia (Oreochromis niloticus). This study was conducted in October and November 2018. The Wet Laboratory Faculty of Fisheries and Marine Kastela Khairun University Ternate. The design used in this study is 
completely randomized design (CRD) with 4 treatments and 3 repetitions. The treatment used is the addition of sago flour A $20 \mathrm{~g}$ of 100 grams of feed, B sago 25 grams of 100 grams of feed, $C 30$ grams of 100 grams of feed, D commercial diet (control).The results showed that The highest absolute growth contained in the commission of $D$ commercial feed (control) amounting to 8.54 grams, followed by 5.98 grams $C$ treatment, treatment of $B$ of 5.64 grams and 4.84 grams of treatment A. Growth shortly SGR highest value obtained on treatment $D$ commercial diet (control) of 3.87 grams followed by treatment $C$ 3,82 grams, 3.81 grams of treatment $B$ and the lowest treatment $A$ that is 3.80 gram. The survival rate of tilapia fish for 28 days in each treatment has the same value, it is $100 \%$.

Key words: Tilapia, Growth, Survival Rate

\section{Pendahuluan}

Ikan nila (Oreochromis niloticus) merupakan salah satu komoditas perikanan yang digemari masyarakat dalam memenuhi kebutuhan protein hewani karena memiliki daging yang tebal serta rasa yang enak. Ikan nila juga merupakan ikan yang potensial untuk dibudidayakan karena mampu beradaptasi pada kondisi lingkungan dengan kisaran salinitas yang luas (Hadi $d k k ., 2009$ )..

Salah satu faktor penting yang mempengaruhi pertumbuhan ikan adalah pakan. Pakan merupakan salah satu unsur penting dalam kegiatan budidaya yang menunjang pertumbuhan ikan budidaya. Pakan pada kegiatan budidaya umumnya adalah pakan komersil yang menghabiskan 60-70\% dari total biaya produksi yang dikeluarkan (Arief $d k k$., 2004). Pakan yang selama ini digunakan oleh para pembudidaya ikan adalah pakan komersil yang memiliki harga yang mahal. Pada dasarnya pakan alternatif bisa diramu sendiri dengan melihat karakteristik bahan baku yang dipilih supaya tetap terjaga ketersediaannya secara kualitas dan kuantitas. Disamping itu, bahan baku ini harus mudah diperoleh, tidak bersaing dengan kebutuhan manusia, ekonomis dan tersedia sepanjang waktu (Gusrina, 2008). Hal ini yang menyebabkan pentingnya pakan dalam usaha budidaya ikan sehingga pemanfaatan bahan baku lol dalam meramu pakan ikan adalah hal yang penting. Alternatif bahan baku lokal yang tetap memilik kandungan protein yang tinggi salah satunya adalah ulat sagu.

Ulat sagu mengandung protein $13,80 \%$, lemak $18,09 \%$, dan air $64,21 \%$ (Wikanta, 2005). Ulat sagu juga mengandung berbagai asam amino esensial yang cukup tinggi sehingga dapat menjadi alternatif sumber protein dalam pakan ikan.

\section{Metode Penelitian}

\subsection{Waktu dan Tempat}

Penelitian ini dilaksanakan pada bulan Oktober-November 2018 di Laboratorium basah Fakultas Perikanan dan Kelautan Universitas Khairun, Ternate.

\subsection{Alat dan Bahan}

Alat dan bahan yang digunakan dalam penelitian yaitu Akuarium, Seser, Timbangan analitik, Thermometer, $\mathrm{pH}$ meter, DO meter, Aerator, Alat pencetak pellet, Gelas ukur, Saringan, Pisau dan gunting, Nampan, Baskom, Kamera, Buku 
dan alat tulis. Benih ikan nila Ulat sagu Tepung ikan teri Kacang tanah Ampas tahu Daun ketapang Vitamin Tepung tapioka Air

\subsection{Metode Penelitian}

Metode yang digunakan dalam penelitian adalah metode eksperimen untuk mengetahui pengaruh penambahan tepung ulat sagu pada pakan buatan terhadap pertumbuhan dan kelangsungan hidup benih ikan nila. Dengan menggunakan Rancangan Acak Lengkap (RAL) dengan 4 perlakuan dan 3 kali ulangan. sehingga diperlukan 12 unit percobaan.

\subsection{Pesiapan Penelitian}

\subsubsection{Pesiapan Wadah Penelitian}

Pada tahap persiapan alat dan bahan yang digunakan dalam penelitian ini adalah Aquarium dengan ukuran 70 x 40 x $30 \mathrm{~cm}$ sebanyak 12 unit.

\subsubsection{Pemeliharan Benih Ikan Nila}

Hewan uji yang digunakan adalah benih ikan nila yang diperoleh dari BBI Kota Ternate, Sebanyak 120 ekor dengan panjang $8 \mathrm{~cm}$ per ekor dan berat 4 Gram per ekor. Ikan tersebut di adaptasikan terlebih dahulu dalam bak penampung selama 2 hari sebelum ditebar dalam wadah pemeliharaan (akuarium). Masa pemeliharan ikan selama 29 hari dengan padat tebar 10 ekor di setiap wadah. Sedangkan pakan uji yang digunakan adalah pakan pellet. Yang diramu sesuai formulasi (Lampiran 1).

\subsubsection{Proses Pembuatan Pakan}

Adapun proses pembuatan pakan ikan nila sebagai berikut:

1. Bahan baku pakan yang akan digunakan ditimbang sesuai formulasi (Lampiran 1).

2. Bahan-bahan penyusun pakan yang akan digunakan seperti tepung ulat sagu, tepung kepala ikan teri, tepung ampas tahu, tepung daun ketapang, vitamin dan tepung tapioka ditambakan satu persatu ke dalam wadah kemudian ditambahkan air sambil melakukan pengadukan hingga bahan menjadi homogen.

3. Setelah proses pencampuran selanjutnya bahan yang suda homogen dicetak mengunakan mesin pencetak pellet.

4. Pakan formulasi basah yang suda dicetak kemudian dipotong sesuai bukan mulut benih ikan Nila dan hasilnya dikeringkan selama 1-2 hari tergantung pada cuaca.

\subsubsection{Pemberian Pakan Uji}

Jenis pakan yang digunakan adalah pakan pellet yang sudah diramu dengan kandungan komposisi pakan. Selama pemeliharaan ikan uji diberi pakan buatan secara Ad libitum (sampai kenyang) dengan frekuensi pemberian pakan sebanyak 3 kali sehari (08:00 - 15:00 - 23:00 WIT). Pemberian pakan dilakukan secara manual atau ditebar sedikit demi sedikit ke dalam setiap unit percobaan.

\subsection{Pengambilan Data penelitian}

Untuk mendapatkan data selama penelitian, maka yang diamati adalah:

a. Berat awal benih ikan nila pada awal penelitian

b. Berat akhir benih ikan nila pada akhir penelitain 
c. Kualitas air disaat penelitian

d. Jumlah ikan yang hidup pada akhir penelitian

\subsubsection{Pertumbuhan Spesifik Mutlak}

Pertumbuhan mutlak atau pertambahan bobot dihitung dengan rumus Everhart et al (1975) dalam Effendie (1997), yaitu: $\mathrm{W}=\mathrm{Wt}-\mathrm{Wo}$

Keterangan:

$\mathrm{W}=$ Pertumbuhan mutlak.

$\mathrm{Wt}=$ Bobot total ikan uji pada akhir percobaan.

Wo $=$ Bobot total ikan uji pada awal percobaan.

percobaan dianggap homogen.

\subsubsection{Laju pertumbuhan spesifik}

Rumus laju pertumbuhan spesifik dengan menggunakan rumus Asmawi (1983):

Keterangan :

$$
\mathrm{SGR}=\frac{(\ln w \mathrm{t}-\ln w o)}{\mathrm{t}} \times 100 \%
$$

SGR = Laju pertumbuhan spesifik

$\mathrm{W}_{\mathrm{t}}=$ Berat ikan pada waktu ke-t $(\mathrm{g})$

$\mathrm{W}_{0}=$ Berat ikan pada waktu ke-0 $(\mathrm{g})$

$\mathrm{t}=$ Lama pemeliharaan ikan (hari)

\subsubsection{Kelangsungan Hidup (SR)}

Kelangsungan hidup ikan dihitung menurut Effendie (1997) sebagai berikut:

$\mathrm{Nt}$

$$
\mathrm{SR}=\frac{----\mathrm{x}}{\mathrm{No}} 100 \%
$$

Keterangan :

$\mathrm{SR}=$ Kelangsungan hidup $(\%)$

$\mathrm{Nt}=$ Jumlah Ikan yang hidup pada akhir percobaan (ekor).

No $=$ Jumlah ikan yang hidup pada awal percobaan (ekor).

\subsection{Parameter Lingkungan}

Parameter kualitas air yang diukur dalam penelitian ini adalah suhu, $\mathrm{pH}$ dan DO. Dimana pengukuran suhu, pH, dan DO, Amoniak, Fosfat. Diukur pada saat Awal dan Akhir penelitian.

\subsection{Analisis Data}

Analisis data menggunakan model matematis Rancangan Acak Lengkap (RAL) Menurut Steel dan Torrie (1993) adalah sebagai berikut:

$$
\mathbf{Y i j}=\boldsymbol{\mu}+\boldsymbol{\pi} \mathbf{i}+\sum \mathbf{i j}
$$

Keterangan:

Yij=Nilai pengamatan pada perlakuan ke-i dan ulangan ke-j

$\mathrm{I}=1,2,3$

$\mathrm{J}=1,2,3$

$\mu=$ Nilai tengah perlakuan

$\sum \mathrm{ij}=$ Pengaruh error perlakuan ke-i dan ulangan ke-j 
Apabila perlakuan yang dicobakan memberikan pengaruh yang berbeda terhadap perubah yang diamati, maka akan dilanjutkan dengan uji beda nyata terkecil (BNT).

\section{Hasil Dan Pembahasan}

\subsection{Pertumbuhan Mutlak}

Hasil pengukuran pertumbuhan berat mutlak benih ikan nila untuk setiap perlakuan diperoleh dari selisih antara berat pada akhir penelitian dengan berat pada awal penelitian. Pertumbuhan mutlak benih ikan nila pada setiap perlakuan dapat dilihat pada Gambar 4.

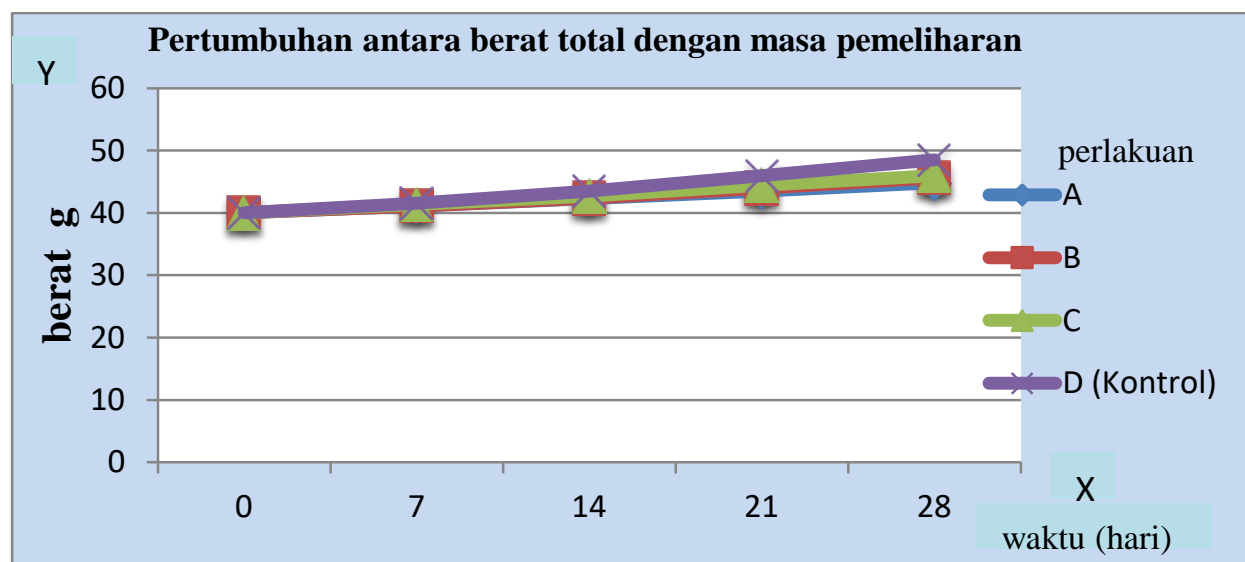

Gambar 4. Grafik Pertumbuhan Berat Mutlak Benih Ikan Nila selama penelitian

Grafik 4 di atas terlihat bahwa laju Pertumbuhan mutlak benih ikan nila pada setiap perlakuan setiap minggu mengalami peningkatan pertumbuhan dengan selisih pertumbuhan dilihat pada grafik diatas. Pertumbuhan mutlak benih ikan nila pada setiap perlakuan memiliki nilai yang berbeda antara setiap perlakuan. Pertumbuhan mutlak tertinggi terdapat pada pelakuan D kontrol sebesar 8,54 gram, diikuti perlakuan $\mathrm{C}$ sebesar 5,98 gram, perlakuan B sebesar 5,64 gram dan perlakuan A sebesar 4,84 gram. Nilai tersebut menunjukan bahwa pertumbuhan mutlak benih ikan nila pada perlakuan D kontrol memberikan hasil yang tertinggi dan perlakuan A yang paling rendah.

Grafik pertumbuhan mutlak rata-rata di atas menujukkan pertumbuhan benih ikan nila pada semua perlakuan setiap minggu mengalami peningkatan. Hal ini disebabkan karena pakan yang diberikan suda direspon dengan baik oleh ikan, sehingga kebutuhan makan ikan juga meningkat hal ini membuktikan bahwa semakin meningkat kuantitas protein pakan maka semakin efektif untuk pertumbuhan berat ikan (Utojo, 1995).

Pertumbuhan yang tertinggi pada perlakuan D kontrol yang diberikan pakan komersil disebabkan kandungan nutrisinya yang cukup dan kandungan nutrisi tersebut mampu memenuhi kebutuhan dasar benih ikan nila dalam merangsang pertumbuhannya. Menurut Kurnia (2005) nilai kualitas pakan ikan sangat ditentukan oleh seberapa lengkap ketersediaan komponen penyusunnya, maka semakin tinggi pula kualitas pakan tersebut. Komponen pakan yang lengkap itu meliputi protein, lemak, karbohidrat, vitamin dan mineral.

Pada perlakuan A,B,C yang diberikan pakan pellet dengan penambahan tepung ulat sagu suda dapat memenuhi kebutuhan ikan nila, kandungan gizi dalam 
pakan pellet dengan penambahan tepung ulat sagu yang diberikan diduga dipengaruhi oleh kandungan energi non protein dan kualitas pakan serta daya cerna ikan yang menyebabkan pertumbuhan mutlaknya tidak optimal bila dibandingkan pakan pellet komersial dengan mengandung protein yang optimal. Menurut Linder (1992), nutrisi merupakan salah satu aspek yang sangat penting dalam budidaya ikan.

Untuk melihat Pengaruh penambahan tepung ulat sagu pada pakan buatan dengan kandungan yang berbeda terhadap pertumbuhan mutlak benih ikan nila maka dilakukan analisis sidik ragam, yang hasilnya dapat dilihat pada Tabel 3

Tabel 3. Analisis sidik ragam pertumbuhan mutlak benih ikan nila

\begin{tabular}{|l|c|c|c|c|c|}
\hline Sumber Keragaman & DB & JK & KT & $\mathbf{F}_{\text {hitung }}$ & $\mathbf{F}_{\text {tabel }}$ \\
\hline Perlakuan & 3 & 2,055 & 0,685 & $13,173^{*}$ & $1 \%$ \\
\hline Galat & 8 & 0,417 & 0,052 & & 7,59 \\
\hline Total & 11 & 2,472 & & & \\
\hline
\end{tabular}

Ket $: *$ Sangat Berbeda Nyata

Berdasarkan Tabel 4, pengaruh perlakuan terhadap pertumbuhan mutlak benih ikan nila dengan penambahan tepung ulat sagu pada pakan pellet menunjukan bahwa nilai $\mathrm{F}_{\text {hitung }}>\mathrm{F}_{\text {tabel }}(1 \%=7,59)$, maka $\mathrm{H}_{0}$ ditolak dan dilanjutkan uji BNT. Berdasarkan hasil perhitungan uji BNT (Lampiran 2) menunjukkan bahwa perlakuan $\mathrm{B}$ dan perlakuan $\mathrm{C}$ berbeda nyata dengan perlakuan A, sedangkan perlakuan $\mathrm{D}$ kontrol sangat berbeda nyata dengan perlakuan A, B dan C. Dari hasil kesimpulan uji BNT pada perlakuan D sangat berbeda nyata dengan perlakuan $\mathrm{A}, \mathrm{B}$ dan $\mathrm{C}$ dilihat dari $\mathrm{F}_{\text {tabel }} 1 \%$.

\subsection{Laju Pertumbuhan Spesifik (SGR)}

Laju pertumbuhan spesifik adalah laju pertumbuhan harian atau persentase pertambahan bobot ikan setiap harinya. Pertumbuhan relatif benih ikan nila setiap perlakuan dapat dilihat pada Gambar 5.

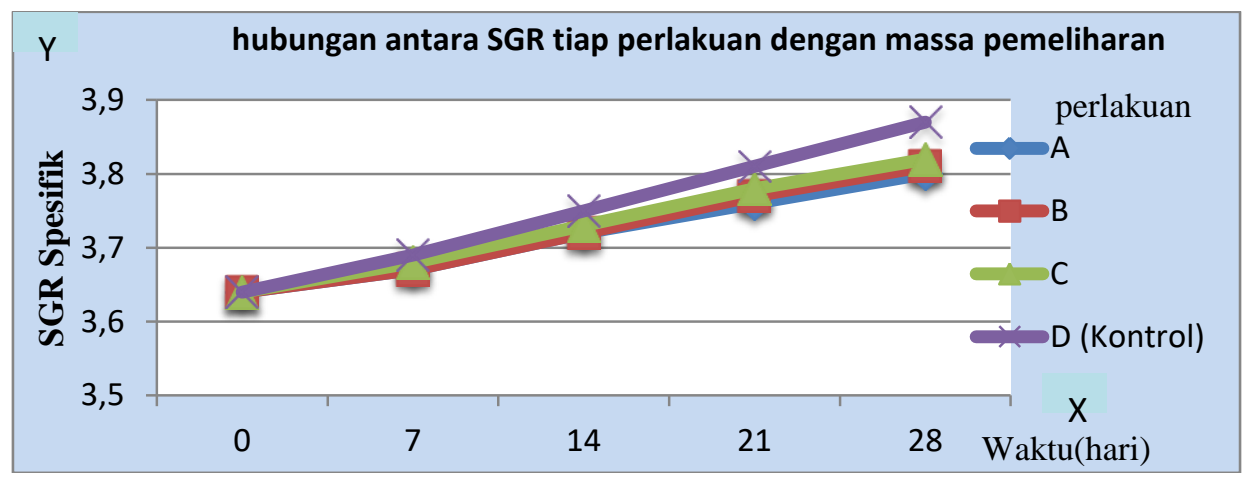

Gambar 5. Grafik SGR ikan Nila selama penelitian.

Grafik 5 di atas terlihat bahwa laju pertumbuhan spesifik benih ikan nila pada setiap perlakuan mengalami peningkatan pertumbuhan pada setiap minggu dimana pertumbuhan dilihat pada grafik pertumbuhan , Pertumbuhan benih ikan nila yang tertinggi pada perlakuan D (kontrol) sebesar 3,87 gram di ikuti dengan 
perlakuan C sebesar 3,82 gram, perlakuan B sebesar 3,81 gram dan yang terendah perlakuan A yaitu sebesar 3,80 gram. Perbedaan tersebut diduga dipengaruhi oleh jumlah penambahan tepung ulat sagu yang diberikan. Laju pertumbuhan harian benih ikan nila disebabkan ikan mampu memanfaatkan nutrien pakan untuk disimpan dalam tubuhnya dan mengkonversinya menjadi energi (bahan bakarnya). Energi ini digunakan untuk metabolisme dasar, perawatan pada bagian-bagian tubuh, pergantian sel-sel yang telah rusak dan untuk pertumbuhan. Hal ini sesuai dengan pernyataan Utojo, (1995) bahwa laju pertumbuhan ikan akan meningkat seiring dengan meningkatnya kadar protein pakan. Protein pada pakan digunakan ikan untuk pemeliharaan tubuh, pertumbuhan jaringan atau penambahan protein tubuh dan penggantian jaringan yang rusak. Pertumbuhan ikan dapat di pengaruhi oleh faktor internal dan faktor eksternal. Faktor internal yang meliputi sifat genetika dan kondisi fisiologis ikan tersebut serta faktor ekternal diantara kompsisi kimia air, suhu air, ketersedian DO, dan pakan ikan

Tabel 4. Analisis sidik ragam pertumbuhan spesifik (SGR) benih ikan nila

\begin{tabular}{|c|c|c|c|c|c|}
\hline & & & & & $\mathrm{F}_{\text {tabel }}$ \\
\cline { 5 - 6 } SumberKeragaman & $\mathrm{DB}$ & $\mathrm{JK}$ & $\mathrm{KT}$ & $\mathrm{F}_{\text {hitung }}$ & $1 \%$ \\
\hline Perlakuan & 3 & 0,001 & 0,0003 & $3^{*}$ & 7,59 \\
\hline Galat & 8 & 0,001 & 0,0001 & & \\
\hline Total & 11 & $0,002$. & & & \\
\hline
\end{tabular}

Berdasarkan Tabel 4, pengaruh perlakuan teradap pertumuhan spesifik benih ikan nila dengan penambahan tepung ulat sagu pada pakan pellet menunjukan bahwa nilai $\mathrm{F}_{\text {hitung }}<\mathrm{F}_{\text {hitung }}(1 \%=7,57)$, maka $\mathrm{H}_{0}$ dterima dan tidak dilanjutakan uji BNT.

\subsection{Kelangsungan Hidup (SR)}

Kelangsungan hidup benih ikan nila diperoleh dari selisih antara jumlah ikan pada akhir penelitian dibagi pada awal penelitian dikali dengan $100 \%$. Kelangsungan hidup benih ikan nila dapat dilihat pada Gambar 6.

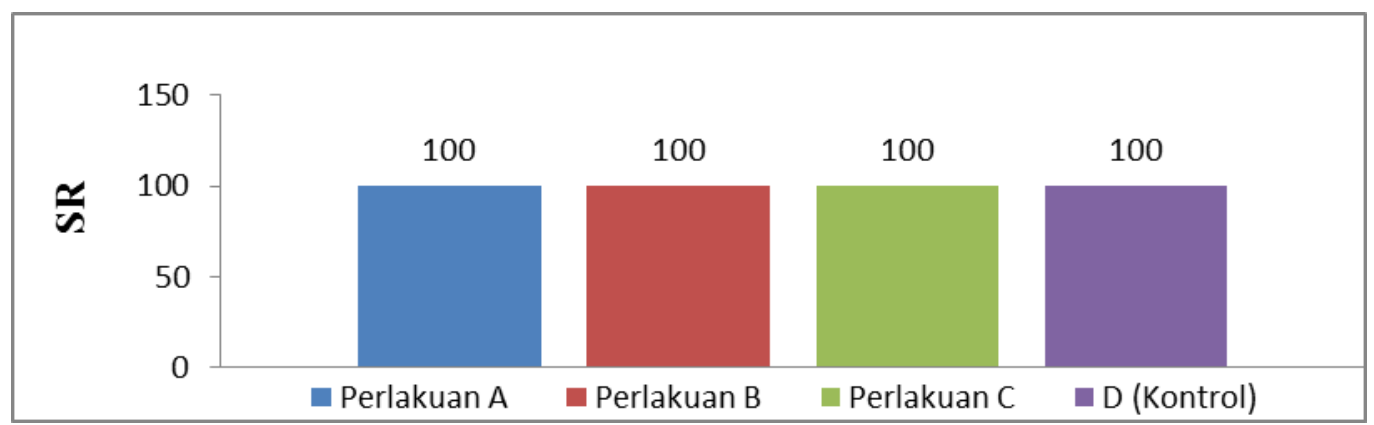

Gambar 6. kelangsungan hidup benih ikan nila 


\subsection{Kualitas Air}

Pengukuran kualitas air dilakukan sebagai parameter pendukung dalam pemeliharan benih ikan nila, serta kualitas air mempunyai peranan yang sangat penting dalam pertumbuhannya. Kondisi kualitas air pemeliharaan benih ikan nila di wadah terkontrol dapat dilihat pada Tabel 5.

Tabel 5. Data Hasil Pengukuran Kualitas Air pada Setiap Perlakuan

\begin{tabular}{ll}
\multicolumn{1}{c}{ Parameter } & Hasil Pengukuran \\
\hline Suhu $\left({ }^{\circ} \mathrm{C}\right)$ & $27,1-28,8$ \\
$\mathrm{pH}(\mathrm{mg} / \mathrm{L})$ & $7,4-7,8$ \\
$\mathrm{DO}(\mathrm{ppm})$ & $5,3-6,6$ \\
Amoniak $(\mathrm{mg} / \mathrm{L})$ & $0,254-0,275$ \\
Fosfot $(\mathrm{mg} / \mathrm{L})$ & $0,104-0,330$ \\
\hline
\end{tabular}

(Sumber : data penelitian, 2019)

\subsubsection{Suhu}

Suhu air pada masa pemeliharan antara perlakuan dan ulangan memiliki nilai yang sama dan konsisten yaitu berkisar antara $27,1-28,8^{\circ} \mathrm{C}$, kisaran tersebut berada pada kisaran optimal bagi pertumbuhan ikan nila. Menurut Kordi (1997), suhu yang baik untuk perkembang biakanya ikan nila berkisar antara $25-30^{\circ} \mathrm{C}$.

\subsection{2 pH}

Nilai $\mathrm{pH}$ air pada masa pemeliharan benih ikan berkisar 7,4-7,8, nilai tersebut layak untuk kehidupan ikan nila. Menurut Kordi (1997), pertumbuhan yang optimal bagi kehidupan benih ikan nila berkisaran antara 7-8. Hal ini selaras dengan Prakoso (2014) bahwa sebagian besar organisme akuatik sensitif terhadap perubahan $\mathrm{pH}$, dan lebih menyukai $\mathrm{pH}$ netral yaitu antara 7-8,5.

\subsubsection{Oksigen Terlarut}

Nila kandungan oksigen terlarut yang ditemukan selama penelitian berkisar anatar 5,3$6,6 \mathrm{mg} / \mathrm{L}$, kisaran tersebut sangat layak untuk pemeliharan ikan nila. Oksigen terlarut sangat berpengaruh terhadap pertumbuhan dan kelangsungan hidup ikan nila. Muslimin $d k k$. (2011) menyatakan bahwa oksigen terlarut yang masih dalam kisaran optimum untuk pemeliharan benih ikan nila berkisar antara 5,4-6,2 $\mathrm{mg} / \mathrm{L}$.

\subsubsection{Amoniak}

Berdasarkan uji analisis laboratorium kandungan amoniak pada awal dan akhir penilitian. Amonia pada awal penelitian berkisar antara perlakuan A 0.267, B 0.275, C 0.254, D 0.259 dan pada akhir penelitian berkisar antara perlakuan A $0.258, \mathrm{~B} 0.263$, C 0.267 , D $0.265 \mathrm{mg} / \mathrm{L}$, kandungan tersebut masih tergolong aman bagi kehidupan benih ikan nila. Hal ini sesuai dengan pernyataan Prihartono (2006) bahwa kadar kritis ikan terhadap kadar amoniak terlarut dalam air adalah 0,6 ppm.

\subsubsection{Fosfat}

Kandungan fosfat pada awal dan akhir penilitian. Amonia pada awal penelitian berkisar antara perlakuan A 0.295 , B 0.195, C 0.213, D 0.104, dan pada akhir penelitian berkisar antara perlakuan A 0.199 , B 0.330 , C 0.309 , D $0.214 \mathrm{mg} / \mathrm{L}$. kandungan fosfat tersebut tergolong tingkat kesuburannya tinggi. Menurut Ebeling $d k k$. 2006 konsentrasi fosfat yang baik untuk budidaya ikan adalah $0,2-1 \mathrm{mg} / \mathrm{L}$.). 


\section{Kesimpulan}

Penambahan tepung ulat sagu yang berbeda memberikan pengaruh terhadap pertumbuhan benih ikan nila. Pemberian tepung ulat sagu dengan dosis 30 gram dari 100 gram pakan memberikan pertumbuhan terhadap benih ikan nila.

\section{Daftar Pustaka}

Arief, M., I. Triasih dan W. P.Lokapirnasih. 2004. Pengaruh Pemberian Pakan Alami dan Pakan Buatan terhadap Pertumbuhan Benih Ikan Betutu (Oxyeleotris marmorata Bleeker.). Jurnal Ilmiah Perikanan dan Kelangsungan Volum 1

Effendie, M.I. 1997. Biologi Perikanan. Yayasan Pustaka Nusatama, Yogyakarta.

Ebeling, J. M., C.F. Welsh, K.L. Rishel. 2006. Performance Evaluationof an Inclined Belt Filter Using Coagulation/Flocculation Aids for the Removal of Suspended Solid sand Phosphorus from Microscreen Backwash Effluent. Aquaculture Engineering, 35: 61-77.

Gusrina. 2008. Budidaya Ikan Jilid 2. Direktorat Pembinaan Sekolah Menengah Kejuruan. Jakarta.

Hadi, M., Agustono dan Y. Cahyoko. 2009. Pemberian tepung limbah udang yang difermentasi dalam ransum pakan buatan terhadap laju pertumbuhan, rasio konversi pakan dan kelangsungan hidup benih ikan nila. Universitas Airlangga.

Kordi, K.M.G.H. 1997. Budidaya Ikan Nila. Dahara prize. Semarang.

Kurnia, A.2005. Aklimatisasi Benih Ikan Nila (Oreochromis sp.) dengan Pencampuran Air Gambut. Jurnal Ilmu Hewan Tropika. 1 (2): 78-82 Agus G.T.K., 2002. Budidaya Gurami. AgroMedia Pustaka: Jakarta.

Linder M. C. 1992. Biokimia nutrisi dan metabolisme dengan pemakaian secara klinis. Department of Chemistry. California State University. Fullerton. Penerjemah Aminudin Paralkasi. UI Press. 781 hal.

Mudjiman.2000. Makanan Ikan. Penebar Swadaya. Jakarta.

Muslimin, M. J. Jairin dan N.B.P. Utomo. 2011. Maskulinisasi ikan nila (Oreochromis niloticus) dengan pemberian testis. Sapi. Jurnal Akuakultur Indonesia. Vol. 10 (1): 5158 hal.

Prakoso, T. 2014. Pengaruh suhu yang berbeda terhadap laju pertumbuhan benih ikan Gurami (Osphronemus gouramy lac) di dalam akuarium [skripsi]. Pangkalan Bun: Program Studi Budidaya Perairan, Fakultas Pertanian, Universitas Antakus.

Utojo. 1995. Pengaruh Kadar Protein Pada Pakan Buatan Terhadap Pertumbuhan dan Kelangsungan Hidup Ikan Kakap Putih (Later calcarifer Bloch). Jurnal Penelitian Perikanan Indonesia I (4) : 37-48.

Wikanta, T. 2005. Analisa Kimia Kandungan Gizi Larva Kumbang Merah Kelapa (Rhynchophorus ferrugineus Olivier). Pusat Riset Pengolahan Produk dan 